\title{
Political Will and Strategic Planning in theImplementation of Universal Basic Education in Nigeria: The Obafemi Awolowo Example
}

\author{
Akinjide Aboluwodi* \\ Faculty of Education, Adekunle Ajasin University \\ Akungba-Akoko, Nigeria
}

\begin{abstract}
In Nigeria, the introduction of Universal Basic Education is meant to reduce the problem of illiteracy, ignorance and povertyto the barest level; a goal it shares with the goals of the World Conference on Education For All. It is meant to aid rapid national economic and political development. Its implementation has become a major challenge; hence its success has been marginal across the country. Among the factors identified as hindering its success are lack of political will on the part of government, absence of strategic planning, inaccurate data, politicisation of the programme and improper funding. Back in 1955, the then Prime Minister in Western Nigeria ${ }^{1}$ Obafemi Awolowo introduced a similar programme, Universal Primary Education with strong commitment and determination. The same commitment, determination and political will that helped Awolowo meet the objectives of his programme arewhat the government can apply to sustain and advance the current Universal Basic Education programme.
\end{abstract}

Keywords: Universal basic education, strategic planning, political will, implementation policy, economic and political development

\section{Introduction}

Dabney once remarked that "universal education is not a blessing, but a bane to the cultural norms of a nation" (as cited in Simpson, 2006, p. 51). This remark was made in response to the statistics he obtained on criminal activities of some American children decades ago. In a study carried out to determine the rate of crimes in Agricultural South and Industrial North, it was discovered that the rate of criminal activities was high in North America where there was universal education compared to the South where literacy rate was minimal. Dabney was forced to conclude hastily, in spite of the fact that other factors could be responsible for such a high rate in crimes, that universal education which was obtained in the North was the cause of the crimes. This remark by Dabney may likely sound offensive to intellectuals such as Rao $(2007$, p. 122) who have argued that basic education 
is not only a means of preserving culture and passing on social values but a veritable means of achieving economic and social development. At least, from the Africans' point of view, the significance of Universal Basic Education was demonstrated by the Conference on Education For All held in Dakar, a capital city of an African country in 2000.

Interestingly, Nigeria affirms the Jomtien and Dakar Declarations by its adoption of the Universal Basic Education programme in order to solve the problem of illiteracy, poverty and ignorance in the country and to achieve sustainable development. However, the implementation of the programme in Nigeria has become so contentious that it has only had a marginal success. This paper highlights the present problems of implementing the Universal Basic Educationprogramme in Nigeria and shows that determination, commitment and political will used by Awolowo as strategies for his Universal Primary Education programme in Western Nigeria (see note 1) back in 1950s could be adopted by Nigerian government in order to achieve effective implementation of its Universal Basic Education.

\section{Nature and Characteristics of Universal Basic Education}

The introduction of Universal Basic Education is part of the global initiatives to achieve Education For All (EFA) in 2015 and to reduce the problem of illiteracy and ignorance in Nigerian societyto the barest level. In response to the global initiatives to achieve Education For All, the Federal Government launched the Universal Basic Education (UBE) programme in 1999. Prior to this, the government of General Olusegun Obasanjo had launched a Universal Primary Education in 1976 in what Labo-Popoola, Bello, and Atanda (2009) claimed to be the government's attempt to make "universalisation of the primary education a national project." The programme, as claimed by Aluede (2006) was abandoned mid-way. The introduction of Universal Basic Education came at a time when the world was in need of efforts to tackle the problems of illiteracy, ignorance and diseases.

In the context of Nigeria, universal basic education comprises early childhood education, six years of primary education and three years of junior secondary school education. Then there is also the non-formal programme which is set to take care of those who dropped out of school. According to Obanya (2004), the target clientele (children, adolescents, youth and adults) are those whose basic learning needs can be met in order to effect positive changes in the society. Thus, it incorporates formal, non-formal and informal programmes to achieve Education For All.

Basic education, in this respect, involves the provision of infrastructure, continuous and sustainable in-service training for teachers and giving prominence to skills acquisition in primary and secondary education (Tahir, 2008, p. 200). Further to this explanation, Tahir contends that in Nigeria, Universal Basic Education is designed to ensure free access to education, reduce the rate of dropout to the minimum, make education relevant to the needs of learners and make education a lifelong enterprise. In Nigeria, this notion as represented 
by Tahir is a mere paper work since its implementation has been dwarfed by Nigerian leaders' ineptitude.

According to Tahir (2008), the cardinal concerns of Universal Basic Education are deeply rooted in how to meet the basic learning needs of children, adolescents, youth and adults (p. 194). It is hoped that meeting these basic learning needs will translate to meeting the needs of the society. However, the beneficiaries of the programme are not homogenous; hence, each beneficiary is expected to achieve its basic needs through the Universal Basic Education programme. Thus, Universal Basic Education programme emphasises 'education' rather than schooling and this has been the view of Obanya (2004, p. 62), who says that the curriculum of Universal Basic Education goes beyond the famous 'three Rs'. As he aptly puts it, "it is determined by the basic survival needs of the beneficiary" (p. 62). In other words, it has to do with the all-round development of the child. It is a life-long learning programme aiming at improving the literacy level of the children and adults by 2015. In Obanya's (2004) view, the emphasis is on literacy, basic needs and continuing education, that is education in its totality.

These aspects are well reflected in the objectives of UBE in Nigeria as noted below (Federal Republic of Nigeria [FRN], 2000):

a. developing in the entire citizenry strong consciousness for education and a strong commitment to its rigorous promotion.

b. the provision of free, universal basic education for Nigerian child of school going age.

c. reducing drastically the incidence of dropout from the formal school system (through improved relevance, quality and efficiency).

d. catering for young persons who, for one reason or another, have had to interrupt their schooling as well as other out of school children, adolescence, through approaches to the provision and promotion of basic education.

e. ensuring the acquisition of appropriate level of literacy, numeracy, manipulative and life skills as well as the ethical moral and civic values needed for laying a solid foundation for lifelong learning.

With the UBE Act of 2004, three areas are specifically designated for the programme, these are; (a) formal basic education encompassing the first 9 years of schooling (primary and junior secondary education) for all children, (b) nomadic education for school age children of pastoral and migrant fishermen, and (c) literacy and non-formal education for out-of-school children, illiterate adults, street children and disabled groups.

Nigeria has the primary aim of achieving a 100 percent enrolment rate in primary school. As part of this primary objective, Nigeria's ultimate goal in her subscription to the goals of Education For All (EFA) is also to improve the quality of life of the individuals within the society in order to achieve sustainable human development (Federal Republic of Nigeria, 2004). However, attitudes of government officials, parents and the community 
members have made the implementation of the programme a mirage. Governments hold back fund and refuse to enforce laws that guide the implementation of the programme, parents refuse to support governments in their efforts while communities are not ready to assist governments in the area of infrastructure (Obanya, 2004, p. 16).

More than a decade ago, Baikie (2000) gave startling figures to show that Nigeria was compelled by the glooming picture of the literacy rate in the country to embrace the global initiative on education in order to arrest the problem of illiteracy. According to him,

Nigeria's literacy rate is estimated at $52 \%$ and out of a population of 21 million children of school-going age, only14.1 million children are enrolled in primary schools aroundthe nation. Completion rate in primary schools is $64 \%$ and the transition from primary to junior secondary school $43.5 \%$. (para. 12)

However, efforts at increasing literacy rate in Nigeria have been overshadowed by political manipulation. Going by the figure released by the United States Embassy in Nigeria, Nigeria's literacy rate in 2012 is estimated at 61 per cent (United States Embassy in Nigeria, 2012). This shows the change in the literacy status of the country in a decade has not been that impressive. This indicates little progress in terms of the provision of basic education in the country.

\section{Issues and Problems of Universal Basic Education in Nigeria}

The Universal Basic Education programme in Nigeria is faced with multiple problems currently making it difficult to achieve the goals of Education For All in 2015. Unfortunately, some of these problems are those that led to the failure of the earlier education systems in the state. Obanya (2004, p. 68), Uko-Aviomoh, Okoh, and Omatseye (2007) and Tahir (2008, p. 192) identify the problems as lack of proper planning and monitoring, politicisation of the programme, improper funding, lack of accurate data, and lack of involvement of teachers in the programme. Therefore, the presence of these problems has made it difficult to achieve close to a hundred percent results in Universal Basic Education in Nigeria.

Interestingly, the major area of focus for government now is the primary and junior secondary education. The other programmes like non-formal education, life-long learning only feature on papers, for lack of adequate strategies to sustain their implementation. Likewise, though governments have tried to sustain the in-service training policy, there has been little or no success in the areas of emphasis on skills acquisition in primary and secondary schools (Obidike \& Onwuka, 2013, p. 186). Equally, the rate of dropout among these secondary school students is still high, "Nigeria has a large number of out-of-school children and young adults with limited literacy and numeracy skills who have little hope of ever joining the formal workforce" (United States Embassy in Nigeria, 2012, p. 1). The number of out-of-school children has continued to rise especially in the Muslim North where the Boko Haram phenomenon has become a scourge and the South East where boys 
now pursue what Obidike and Onwuka(2013) classified as "money-yielding ventures" (p. 186).

There is no sense of commitment and determination (as earlier pointed out) on the part of governments to make the Universal Basic Education programme work. At present, only governments are active in its implementation and communities and families have been passive. The reason for this situation is clear; private schools have almost swallowed the existing public schools especially in the South West where the programme was implementedearlier. Community and individuals who would have assisted have turned their attention to running of private schools. Parents, too, think private schools especially primary and secondary can fill some vacuum (in the area of quality) created by the public schools in Nigeria.

Different studies seem to suggest that the UBE in Nigeria is plagued by a number of problems. According to Labo-Popoola, Bello andAtanda (2009), poor projection as a result of faulty census exercise has impeded implementation of the programs under the UBE. As they contended, "this poor projection is a factor that has affected the universality of primary education in Nigeria" (The challenges section, para. 3). Obidike and Onwuka (2013) identify lack of fund and planning, qualified personnel, effective supervision and poor management as the major factors affecting the implementation of UBE in Nigeria (p.189). In the area of political will to get the programme on course, governments abdicate their responsibility in not being able to enforce the regulations guiding the implementation of the programme. Obidike and Onwuka (2013) further pointed out that "there are no effective legislations or sanctions for whoever fails to send his/her child to school" (p. 189). This assertion points to the practice in the South East where boys now engage in money-making ventures rather than schooling with the connivance of their parents.

The Universal Basic Education Commission (UBEC) gives the UBE target as follows:

a. ensure all school age children attend the school.

b. ensure $100 \%$ transition to junior secondary level at the end of six years of primary school.

c. ensure completers of basic education possess literacy, numeracy and basic life skills.

d. ensure all teachers in basic education institutions possess the Nigerian Certificate of Education

However, available literature and data show that the country is far from achieving these targets. Adamolekun (2013) has shown in a lecture he gave in Joseph Ayo Babalola University (JABU), Ikeji Arakeji, Osun State, on 24 January 2013 examples of failure of Nigerian basic education and argued that the education in the country is in crisis. Below are some examples of problems of Nigerian education, as he presented:

1. From the EFA Global Monitoring Report (2012), 10.5 million Nigerian children of school-going age are not attending school.

2. According to the World Economic Forum's Competitive Report Index, 2011-2012, 
Nigeria was ranked 140th out of 144 countries in primary education enrolment.

3 . As noted by a Minister in 2012, Northern Nigeria has the highest number of schoolage children in the world that are out-of-school.

4. Some states in Nigeria have enrolment as low as $12.0 \%$, even though the UBE programme is supposed to meet the EFA target of 100 percent enrolment in school by 2015.

5. Among 19,125 teachers tested in Primary Four Mathematics in Kwara State in 2008, only seven could attain the minimum benchmark. Only 1 of 2,628 teachers with degree could pass the test and ten graduates scored zero.

Adamolekun, in the same speech, concluded that "muddled political responsibility for UBE has been a major constraint and centralised implementation (for example, contracts for purchase of textbooks for students in all 36 states are awarded in Abuja) has hindered federal-states collaboration that is essential for effective implementation." For him, this inherent weakness of centralised implementation leads to the failure of UBE scheme.

\section{Budgetary Allocation to Education in Nigeria}

Inadequate funding is one of the main reasons for the poor results in efforts towards UBE. Currently, Nigeria has been investing less than nine per cent of its total budget. This makes Nigeria's spending on education very unsatisfactory, far less than many other African countries (Cote d'Ivoire - 30\%, Ghana - 31\%, Burkina Faso, 17\%) and also far less of $26 \%$ as was recommended by UNESCO (Abayomi, 2012). The highest budgetary allocation made to education in recent years was 13 per cent in 2008 which plunged down to seven per cent in 2009 and further went down to about six per cent in 2010 (Olawale, 2010). All these show lack of commitment of the government towards achieving the goals of UBE. With the declaration of the UBE, the Federal Government was supposed to "provide the bulk of funds and the State government would assist sufficiently to ensure that, the poverty stricken parents need to contribute minimal funds" (Okugbe, 2009, p. 185).

Contrary to the present pattern, the time of Awolowo was quite different from the perspective of emphasis given to education. He allocated an average of 35 per cent of total recurrent budget each year to education (Ajayi, n.d.). This followed from the assertion that "as far as possible, expenditure on services which tend to the welfare and health and education of the people should be increased at the expense of any expenditure that does not answer to the same test" (Awolowo, 1960, p. 263). According to Ajayi (n.d.), "[b]etween 1954 and 1966, education attracted the largest share of the Western Region's recurrent budget, having varied between 28.9 per cent and 41.2 per cent during the period. Ajayi went further to show that "the lion share of the budget for education at the time went to primary education alone" (p. 8). This happened when Awolowo was the Premier of Western Nigeria. This was an example of high importance given by a provincial government to education. 


\section{Concepts of Political Will and Strategic Planning}

There are two basic issues lacking in the implementation ofthe Universal Basic Education programme in Nigeria and which are being advocated in this paper. These are the issues bordering on political will and strategic planning. Political will, as Kpundeh (1998) has noted, is directly linked to "demonstrated credible intent of political actors (elected or appointed leaders, civil society watchdogs, stakeholder groups etc.)" (p. 92). Thus for him, political will is manifest in the degree to which reform initiatives are participative and incorporate a range of political actors and civil society. On the other hand, Charney (2009) defines political will as "the combination of three factors: opinion, plus intensity plus salience" (para. 4). Opinion in this regard, is shaped by how issues are framed, and the considerations that frame such opinion decide which way political will is pointing. Intensity explains the strongly or persistently held opinion, in this regard opinion about the issue in question. And salience deals with how the issues are connected with the needs and aspirations of the group or people. Political will, therefore, shows the seriousness of government to issues that anchor on the lives of the people. It deals with the determination to effect changes or reforms in government intended to transform economy, education or politics leading to sustainable development.

Political will determines the effectiveness of planning in how government goes about its daily activities. Planning relates effectively with how government organises its businesses with a view to achieving positive results in governance. Here the question of resource management, accountability and transparency is embedded. Ifideli and Alutu (2011) define planning as "a process of spelling out what to be done, how it is going to be done, with what resources and how the result is going to be evaluated" (p. 93).Planning, therefore, rests on focus, determination and will to succeed. Business organisations usually thrive when planning is combined with strategy (procedure) to effect a change in their structure, vision and the way businesses are conducted. With government, strategic planning is desirable in order to determine the fundamental principles that shape the business of governance. Thus as Farrah, Felix, Greenstern, Hirstch de Haan, and Levin (2001) have argued,

Strategic planning deals with systematic planning process involving a number of steps that identify the current status of the (state) including its mission, vision for the future, operating values, needs (strengths, weakness, opportunities, and threats) goals, prioritized actions and strategies, action plans, and monitoring plans. (p. 4)

Strategic planning, therefore, is how an individual defines his direction, organises and distributes his resources and understands the current situations he needs to shape course of action (Joint United Nations Programme on HIV/AIDS, 1998). The extensive discussion of political will and strategic planning here is to show that the success of any programme undertaken by government requires the efforts of the twin factors - political will and strategic planning. 


\section{Obafemi Awolowo and Free Universal Primary Education Programme in Western Nigeria}

Awolowo's empathy for the indigent but intelligent children was informed by his personal experience in life. He lost his father when he was only eleven years old. This sudden death of his father changed the course of his education as he had to take care of himself because there was no assistance from his uncle (Awolowo, 1968). He attended four primary schools, served as a houseboy and engaged in firewood business. All this he did in order to finance his elementary education. Awolowo got a job as a 'pupil teacher' in his former school, Imo Wesleyan School, Abeokuta, Nigeria, but left after a year for Wesley College, Ibadan (a teachers' college) which he equally abandoned after a year because of his bitter experience with the senior students (Awolowo, 1968, pp. 62-63). Subsequently, he engaged himself as a reporter, money lender, a public letter-writer, a produce buyer and a transporter (Balogun, 2009, p. 63). While he was doing these jobs, Awolowo registered as an external degree student of the University of London where he obtained a Degree of Bachelor of Commerce. He was in London for his LLB where he seized the opportunity to establish the Egbe Omo Oduduwa, a Yoruba welfare association. He returned to Nigeria after a little sojourn in Britain and joined the struggle for the independence of Nigeria (Balogun, 2009, p. 63). In 1954, he became the first Prime Minister of Western Nigeria when the region became one of the federating units of the federal Nigeria.

Awolowo's experience in life coupled with the belief that lack of education is an impediment to healthy and productive living informed his free and compulsory education policy. According to Ajayi (n.d.), "the preparation for it (Awolowo's free education programme) began in 1952when the proposals for the scheme were tabled before the Western House of Assembly" (p. 1). He declared, unequivocally before the House, the need for " $[t]$ he education of all children of school-going age, and the general enlightenment of all illiterate adults and all illiterate children above the school-going age" (Awolowo, 1981a, p. 197). In 1954, the population of the pupils in schools was 456,000; by 1955 when the programme was launched the population increased to 811,432, making an increase of 354,832 . In order to cut the cost of running the programme, Awolowo suggested that the first level, six-year programme should be free and compulsory. This is to prevent some parents from withdrawing their children from school. Subsequently, the second and third levels would become free as soon as sufficient teachers and adequate preparation have been made in the areas of infrastructure and equipment for teaching and learning (Awolowo, 1970, p. 47).

For Adegbesan (1988), "the powerful reason for free education to be treated as a priority (by Awolowo) was to reduce the inequality in the society which has been the most potent cause of deep social and political disaffection in Nigeria" (p. 818). Awolowo attached three reasons for free education in Western region, that is, that (a) a truly educated citizenry 
is one of the most formidable deterrent to dictatorship, oligarchy and feudal authority, (b) an educated individual is the strongest single factor in the rapid economic and social advancement to any nation, and (c) the pursuit of equal educational opportunity for all in order to achieve welfare state (Adegbesan, 1988, p. 817). If these demands are met by the Party, Awolowo hopes to achieve economic prosperityand meet the social and economic needs of the people through mass education.

According to Ajayi (n.d.), Awolowo's UPE "scheme was indeed an epoch-making event, which quantitatively represents a very impressive achievement" (p. 10). Ajayi identifies the following as the major achievements of the program:

1. Western region where the scheme was launched had 50 percent of children between the ages of six and twelve years as beneficiaries. The Northern region with a high population had less that 20 percent of its young ones in school during this period (see United States Embassy in Nigeria, 2012).

2. Ajayi noted that "the scheme provided a wider base from which the secondary schools and teacher training colleges drew their entrants" (p. 10).

3. As a result of the Universal Education Programme, people in the region enjoyed a greater proportion of material benefits and modernisation (Ajayi, n.d).

4. According to Ajayi, "the era broke the myth and indifference towards female education" (pp. 10-11). By 1966, 10 years after the launch of the scheme, "almost two out of five [pupils] were girls" (p. 11). Thus for Ajayi, the investment in the education of increasing numbers of future mothers has paid rich dividends especially in Western Nigeria.

5. Adamolekun (2013) avers that "the launch of (Awolowo's) universal primary education was accompanied by rapid expansion of post-primary education: 5-year Secondary/Grammars and 3-year Modern Schools" (p. 2).

6. Awolowo (1960) submitted that "at the time of my departure the number of Nigerians in the higher rung of the civil service in the West (Nigeria) was 1,275, that is, 75 percent of the total actual strength of senior officers as against 18 percent in 1952" (p. 293). The reason for the rise in the strength of civil service is as a result of Awolowo's UPE in Western Nigeria. Thus, the Free Universal Primary Education (FUPE) programme initiated and implemented by Awolowo puts Western Nigeria ahead of all the other regions in Nigeria. Mustapha $(2009$, p. 9) citing Yoloye (1989, p. 55) alluded to the success of Awolowo's FUPE with the contention that by 1960 "...the Western Region had 47.3 per cent of the students at the University College Ibadan, the Eastern Region had 39.8 per cent and Northern Nigeria only 8. 4 per cent" (p. 8). In the areas of political sophistication and economic growth, Western region towers above other regions in Nigeria. 


\section{Awolowo's Planning Strategies: Implications for UBE Programme in Nigeria}

The implementation of the programme was guided by three principles, namely, principles bordering on the social desirability of free education, its financial practicability and whether it should be the priority of government. Answers to questions involving these principles revolve around the belief that education is a requisite for social consciousness, hence attacking the problem of illiteracy, ignorance and poverty is a necessary condition for national development (Awolowo, 1981b, p. 165). Thus, adequate planning made iteasy to achieve an effective implementation of the programme, and this was assisted by the principle which says that no nation can develop optimally if her citizens remain largely illiterates Awolowo, 1981b). Awolowo demonstratedthat education was essentially linked with development in 1955 in Western Nigeria. It was a zeal that placed the region ahead of others in Nigeria.

Awolowo's planning strategies included defining his mission which was backed by vision of what education would do to his region in the future. Part of this planning is the reduction in financial wastes and training of teachers to implement the programme. Over and above this, Awolowo and his party set up monitoring teams to oversee the implementation of the entire programme. This is what the Nigerian government does not do, hence its inability to sustain an effective implementation of the programme. It is imperative for Nigeria to adopt this monitoring strategy to be able to know how the programme is being implemented by the different agencies and states.

In order to implement the scheme Awolowo (1981b, p. 08) defined his mission, “... we were not only concerned with the children of the time who are now great adults, we were also concerned about those of you who were yet to come into the world." Awolowo introduced Education and Health levy of ten shillings per male adult taxpayers throughout the Region. Awolowo predicted "when they begin to enjoy the delectable fruits of the education and health levy which they are now being called upon to pay, will now and in future remember us with gratitude..." (p. 108). Thirty-one year later, Awolowo retorted "The youngest of the scheme are now 31 years of age. It stands to reason, therefore, to say that many of them now occupy important positions in all the spheres of useful activities throughout Federal Republic of Nigeria" (p. 108). Summing up, Enoh (1996, p. 105) contended that Awolowo proposed a wide range of steps including increased generation of revenue, cutting of government wastes and the making of modest plan. The clear implication of this is that if UBE is to succeed its mission must be well-defined and strictly followed.

Awolowo considered the programme as socially desirable, hence his efforts to evolve viable strategies which include getting in place groups that were to provide reliable and appropriate data on the scheme. Besides, he set up monitoring groups that monitored the construction of low-cost classrooms for the programme (Awolowo, 1981b, p. 184). Tsafe 
(2013, p. 23) contended that "...effective planning strategies should be put in place using reliable and appropriate data banks in UBE scheme." Building of cheap but enduring blocks of classrooms as done by Awolowo during his time, and training of teachers in Teachers' College rather than the crash programme being undertaken by the Nigerian Teachers Institute will help to ensure qualitative Universal Basic Education programme in Nigeria. Baikie's (2000) assertion about fourteen years ago is still relevant today. According to him, if the ministries have been planning properly, renovating and equipping schools, have an organised teacher training programme for the production of teachers...the decadence of the education system will not be in suchglaring evidence as to necessitate imposing an educational scheme thatwill be run on emergency basis.

Though government tacitly says that "education shall continue to be highly rated in the national development plans because education is the most important instrument of change..." (FRN, 2004, p. 8), it does not match this statement with action. However, in Awolowo's time, he gave high priority to education and spent highest proportion of the national budget on education because of the belief that no nation can develop optimally without education. If Nigerian leaders share this thought, they will make adequate budgetary allocation to the UBE programme.

For Awolowo, “...the dutiful propaganda, with which we promoted its (FUPE) inauguration, has been such that the ignorance and prejudice which used to make our people to prefer sending their children to farms rather than to school have been broken down" (1981b, pp. 108-109). Governments may not use this propaganda approach as a tool to enlist parents' support in sending their wards to schools. The traditional rulers are readily available to collaborate with any agencies of governments to sensitize parents on the importance of education to individual and nation's development. The North and South East Nigeria require this approach to be able to get their people back to school. As LaboPopoola, Bello and Atanda (2009) have suggested, "government must have the political will to put into effect the Act that stipulates penalties for parents who refuse to send their children or wards to school" (p. 267). Awolowo demonstrated this political will in his programme, hence the view by Aderinoye and Laoye (2008) that "if not for the political will of Awolowo in 1955 there would have been nothing like the free education programme of the old Western region of Nigeria" (p. 362). Apparently this strategy is essential to the effective prosecution of education policy in Nigeria.

\section{Conclusion}

In clear terms, Nigeria needs to redefine its mission in relation to education delivery. Bah-Diallo (1997) sees this in terms of the redefinition of the school in terms of quality, equity, and efficiency. Perhaps this may involve an increased participation of local communities to ensure quality delivery, access by all and effective re-training of teachers 
for efficient delivery. The state must have a vision which is assisted by planning and political will. This can be done through what Bah-Diallo (1997) classifies as the expression of political will through the declarations of intentions, budget allocations and institutional and legal measures. The budget allocation to education as indicated in this paper does not suggest any sense of commitment on the part of the governments. Effects of such deficit in budget allocation to education are usually felt in areas such as "dilapidated structures, overcrowded classrooms, poor staffing, and unavailability of basic teaching and learning materials" (Nwankwo, 2010, p. 122). Government should demonstrate its willingness to act appropriately in funding education by making a cut "in parties, incessant travels, unnecessary summits, and talk shops..." (Academic Staff Union of Universities, 2013). This may translate to ensuring adequate financial assistance to the various agencies that have direct involvement in the programme.

Government must see education, precisely Universal Basic Education, as socially desirable. In this respect, it has to evolve viable strategies which include getting in place groups that will provide reasonable and accurate data on the Universal Basic Education clientele. There should also be constant re-training of teachers who are involved in the teaching of pupils/students in the Universal Basic Education programme. Finally, there should be a need to monitor the different groups who are involved in any projects organised by the Universal Basic Education Commission for effective implementation of the programme. Nigeria stands to gain immensely from the adoption of those implementation strategies which Awolowo used in his own time to make a success of his Free Universal Primary Education programme.

Given its specific objective of meeting the basic learning needs of the beneficiaries and its elastic nature, Universal Basic Education is designed to achieve Education For All, intended for sustainable human development. In this regard, the government needs to design a new framework that will make the various agents to be committed to the success of the programme. The framework should be able to incorporate Awolowo's planning strategies and translate them into desirable implementation strategies needed for the success of the current Universal Basic Education. The strategies which encompass funding, social desirability of the scheme, construction of blocks of classrooms, and monitoring committee, where required and so on can be adapted for this purpose. Moreover, Nigeria needs to evolve planning strategies and political will to be able to achieve an effective implementation of Universal Basic Education programme.

\section{Note}

1 Before Nigeria was granted independence by Britain in 1960, the country had three semiautonomous regions, North, West and East. The three regions operated different education policies; each region was guided by its own desire and aspirations. ObafemiAwolowo was the Premier of Western region whose vision was to have a 100 percent literacy in his region. He 
prosecuted the UPE scheme with determination and commitment with the desire to succeed. The success of the programme makes the region stand ahead of others in the areas of infrastructural facilities, political sophistication and economic growth.

\section{References}

Abayomi, A. (2012). 2012 education budget and its implications (analysis). Lagos, Nigeria: Vanguard Publication. Retrieved from http://www.vanguardngr.com/2012/4/2012

Adamolekun, L. (2014). Education sector in crisis: Evidence, causes and possible remedies. Being a text of 2012/2013 distinguished lecture of Joseph Ayo Babalola University (JABU), Ikeji Arakeji, Osun State. Retrieved from http://emotanafricana. com/2012/01/26/education-sector-in-crisis

Aderinoye, R., \& Laoye, D. (2008). Building a learning society for the millennium in Nigeria: Challenges and responsibilities. In M. Boucouvalas \& R. Aderinoye (Eds.), Essays in honour of Professor Michael Omolewa (Vol. 1, pp. 358-375). Ibadan, Nigeria: Spectrum Books.

Adegbesan, P. R. A. (1988). Awolowo and the politics of education in Nigeria. In O. O. Oyelaran et al. (Eds.), Obafemi Awolowo: The end of an era (pp. 812-826). Ile-Ife, Nigeria: Obafemi Awolowo University Press.

Ajayi, S. A. (n.d.). The development of free primary education scheme in Western Nigeria, 1952-66: An analysis. Retrieved from www.ajol.info/index.php/og/article/ download/52320/4044

Academic Staff Union of Universities. (2013). The kernel, propaganda and the way forward: The nation on Sunday. Lagos, Nigeria: The Western Publishers.

Aluede, R. O. A. (2006). Universal basic education in Nigeria: Matter arising. Retrieved from www.medwellpublishing.com/ref.php?doi=pjssci2009/252.259

Awolowo, O. (1960). AWO: The autobiography of Obafemi Awolowo. Cambridge, England: Cambridge University Press.

Awolowo, O. (1968). My early life. Lagos, Nigeria: John West Publication.

Awolowo, O. (1981a). Voice of reason. Akure: Fagbamigbe Publishing.

Awolowo, O. (1981b). Voice of wisdom. Akure: Fagbamigbe Publishing.

Awolowo, O. (1970). Strategy and tactics of the People's Republic of Nigeria. Ibadan, Nigeria: Macmillan.

Baikie, A. (2000). Democracy and education: Implementation of the universal basic education. Retrieved from http:// www.docstoc.com/.../DEMOCRACY-ANDEDUCATION

Bah-Diallo, A. (1997). Basic education in Africa: Topical and sectoralstudies. Retrieved from http://jicairi.jica.go.jp/TFCP_and_JBICI...

Balogun, O. (2009). A philosophical comparison of educational thoughts of Obafemi Awolowo and Tai Solarin. Thought and Practice: A Journal of the Philosophical Association of Kenya, New Series, 1(2),61-72

Charney, C. (2009). Political will: What is it? How is it measured? New York, NY: Charney Research. Retrieved from http://www.charneyresearch.com/resources/political-willwhat-is-it-how-is-it-measured/ 
Enoh, A. O. (1996). Main currents in Nigerian educational thought. Jos, Nigeria: Midland Press.

Farrah, J., Felix, R., Greenstern, H., Hirstch de Haan, E., \& Levin, M. (2001). Strategic planning. Virginia, VA: Foundation for Community Association Research.

Federal Republic of Nigeria. (2000). Implementation guidelines for the Universal Basic Education (UBE) programme. Abuja, Nigeria: Federal Ministry of Education.

Federal Republic of Nigeria. (2004). National policy on education (4th ed.). Lagos, Nigeria: Nigerian Educational Research and Development Council Press.

Ifedili, C. J., \& Alutu, G. (2011). Planning the 9-year universal basic education programme in Nigeria for successful implementation. Ozean Journal of Social Sciences, 4(2), 9399. Retrieved from http://www.ozelacademy.com/OJSS v4n2 5pdf

Kpundeh, S. J. (1998). Political will in fighting corruption. In S. Kpundeh \& I. Hors (Eds), Corruption and integrity improvement initiatives in developing countries (pp. 91-110). New York, NY: UNDP.

Labo-Popoola, S. O., Bello, A. A., \& Atanda, F. A. (2009). Universal basic education in Nigeria: Challenges and way forward. Pakistan Journal of Social Sciences, 6(5), 252269.

Mustapha, A. R. (2009). Ethnic structure, inequality and governance of public sector in Nigeria. Retrieved from http://www.unrisd.org/80256B3C005BCCF9

Nwankwo, O. C. (2010, April). UBE as a basis for sustainable development in Nigeria. Journal of Research in Education and Society: International Perspective, 1(1), 114-128.

Obanya, P. (2004). Educating for the knowledge economy. Ibadan, Nigeria: Mosuro Publishers.

Obidike, N. D., \& Onwuka, L. N. (2013). Enhancing the implementation of Universal Basic Education in Nigeria. Research Journal in Organizational Psychology \& Educational Studies, 2(4), 185-190. Retrieved from www.emergingresource.org

Olawale, O. (2010, April 1). Challenges currently facing the educational sector in Nigeria. The Frontier Post, p. 4

Okugbe, G. E. (2009). The challenges affecting the implementation of the universal basiceducation (UBE) in Delta State, Nigeria. Journal of Social Science, 20(3), 183187.

Joint United Nations Programme on HIV/AIDS. (1998). Guide to the strategic planning process for a national response to HIC/AIDS. Geneva, Switzerland: UNAIDS.

Retrieved from http://data.unaids.org/publications/IRC-pub05/jc44-stratplan...

Rao, B. (2007). Education for all: Achieving the goals (Vol. 3). New Delhi, India: APH Publishing.

Simpson, B. D. (2006). Cultural degradation of universal education: The educational view of Robert Lewis Dabney. Journal of Libertarian Studies, 20(3), 47.

Tsafe, A. K. (2013). A critical analysis of Universal Basic Education on its implementation so far. Journal of Pure and Applied Sciences, 2(1).

Tahir, G. (2008). The universal basic education programme and the challenges for higher education in Nigeria. In M. Boucouvalas \& R. Aderinoye (Eds.), Essays in honour of Professor Michael Omolewa (Vol. II, pp. 189-204). Ibadan, Nigeria: Spectrum Books. 
Uko-Aviomoh, E. E., Okoh, E., \& Omatseye, B. O. J. (2007). Universal Basic Education (UBE) in Nigeria: An appraisal. Education, 17(4), 558-568. Retrieved from http://www. articlearchives.com/education-training/education-system-institutions/9646-1.htm.mk United States Embassy in Nigeria. (2012). Nigeria education fact sheet. Abuja, Nigeria: Author. Retrieved from http://photos.state.gov/libraries/nigeria/487468/pdfs/ JanuaryEducationFactSheet.pdf 